\title{
Koordinasi Bimbingan Konseling dengan Guru Bidang Studi Menghadapi Siswa Berkesulitan Belajar Matematika
}

\author{
Dian Puspita ${ }^{1}$, Rizki Amalia ${ }^{2}$ \\ Universitas Islam Sultan Syarif Kasim Riau Pekanbaru \\ Universitas Pahlawan Tuanku Tambusai Bangkinang \\ Email: 11810523279@students.uin-suska.ac.id
}

\begin{abstract}
Abstrak
Banyak siswa yang menganggap matematika merupakan bidang studi yang paling sulit. Tetapi, semua orang harus mempelajarinya sebab matematika merupakan sarana untuk memecahkan masalah kehidupan sehari-hari. Kesulitan belajar matematika pada siswa harus segera di tangani, karena hampir semua bidang studi memerlukan matematika yang bersesuaian. Koordinasi antara bimbingan konseling dengan guru bidang studi sangat penting untuk mengetahui kesulitan apa yang dialami peserta didik selama proses pembelajaran matematika dan apa penyebab nya serta bagaimana cara menanggulangi kesulitan tersebut.
\end{abstract}

Kata Kunci: Koordinasi, Bimbingan Konseling dengan Guru Bidang Studi, Siswa Berkesulitan Belajar Matematika

\section{PENDAHULUAN}

Menurut The National Joint Committee for Learning Disabilities (NJLD) mengemukakan bahwa :"Kesulitan belajar menunjukkan pada sekelompok kesulitan yang dimatifestasikan dalam bentuk kesulitan yang nyata dalam kemahiran dan penggunaan kemampuan mendengarkan, bercakap-cakap, membaca, menulis, menalar, atau kemampuan dalam bidang studi matematika. Gangguan tersebut intrinsik dan juga disebabkan oleh adanya disfungsi sistem syaraf pusat. Meskipun suatu kesulitan be;ajar mungkin terjadi bersamaan dengan adanya kondisi lain yang mengganggu (misalnya gangguan sensoris, tunagrahita, hambatan sosial dan emosional) atau berbagai pengaruh lingkungan (misalnya perbedaan budaya, pembelajaran yang tidak tepat, faktor-faktor psikogenik), berbagai hambatan tersebut bukan penyebab atau pengaruh langsung." (Abdurrahman : 2015)

Matematika merupakan bidang studi yang dipelajari oleh semua siswa dari SD hingga SMA bahkan sampai ke perguruan tinggi. Ada banyak alasan tentang perlunya matematika diajarkan secara integral kepada siswa. Cornelius mengemukakan lima alasan pentingya matematika dipelajari 1) sarana berpikir yang jelas dan logis, 2) sarana untuk memecahkan masalah kehidupan sehari-hari, 3) sarana mengenal pola-pola hubungan dan generalisasi pengalaman, 4) sarana untuk mngembangkan kreativitas, 5) sarana untuk meningkatkan kesadaran dalam pengembangan budaya. (Hinsa:2017)

Matematika merupakan salah satu keahlian yang harus dimiliki oleh sisiwa. Matematika dianggap mempunyai peran ganda, yaitu sebagai "The Queen of Science" atau sebagai ratu dari ilmu pengetahuan, artinya matematika dapat berdiri sendiri untuk pengembangannya dan juga sebagai 
pelayan ilmu, yaitu matematika bisa dimanfaatkan untuk mengembangkan ilmu lainnya mulai dari ilmu eksakta sampai ilmu sosial sesuai dengan perkembangan teknologi. (Abdul:2018)

Guru adalah salah satu komponen penting dalam pencapaian amanat UU Sistem Pendidikan Nasional No. 20 Tahun 2003 Pasal 3 yang menyatakan bahwa Pendidikan Nasional berfungsi mengembangkan kemampuan dan membentuk watak serta peradaban bangsa yang bermatabat dalam rangka mencerdaskan kehidupan bangsa, bertujuan untuk berkembangannya potensi siswa agar menjadi manusia yang lebih beriman dan bertakwa kepada Tuhan yang Maha Esa, berakhlak mulia, sehat, berilmu, cakap, kreatif, mandiri, dan menjadi warga negara yang demokratis serta bertanggung jawab, dimana guru mempunyai fungsi strategis dalam pengembangan potensi siswa dalam hal ketakwaan, pengetahuan, sikap, dan keterampilan siswa secara keseluruhan. (Melisa:2013)

Bimbingan konseling merupakan suatu proses bantuan atau pertolongan yang diberikan oleh pembimbing kepada individu melalui pertemuan tatap muka atau hubungan timbal balik keduanya, agar individu memiliki kemampuan melihat dan menemukan masalahnya dan bisa menyelesaikannya. Karena ruang lingkup bimbingan konseling yang kita ambil disini adalah sekolah, maka pembimbing disini adalah guru dan individu adalah siswa. (Riki:2016)

Guru bidang studi matematika merupakan guru yang paling strategis tempatnya untuk mengatasi kesulitan belajar matematika. Menyadari akan pentingnya matematika, siswa dituntut dapat mempelajari matematika dengan sungguh-sungguh. Pada realita nya, banyak kita temui siswa dalam belajar matematika mendapatkan hambatan, prestasi yang tidak memuaskan, dan lambat dalam pengerjaan tugas. Siswa seperti ini lah yang bisa kita kelompokkan dalam siswa yang berkesulitan belajar matematika. Guru bidang studi matematika bisa menggunakan layanan bimbingan konseling untuk menanggulangi kesulitan belajar matematika pada siswa. Layanan bimbingan konseling yang dimaksudkan disini misalnya seperti : layanan orientasi, informasi, penempatan dan penyaluran, pembelajaran, konseling perorangan, bimbingan kelompok dan konseling kelompok. Guru bidang studi matematika harusnya melaksanakan ketujuh layanan bimbingan konseling tersebut agar setiap permasalahan yang dihadapi siswa dapat di tanggulangi sedini mungkin sehingga kesulitan belajar matematika tidak lagi dialami siswa. (Afiatin:2018)Tetapi pada kenyataannya, banyak guru bidang studi matematika yang tidak melaksanakan layanan bimbingan konseling dalam pembelajarannya, ini menyebab kan tidak identifikasinya siswa-siswa yang berkesulitan belajar matematika.

Fakta dilapangan menunjukkan bahwa siswa yang mengalami kesulitan belajar di sekolah hampir seluruhnya belum terlayani dengan baik. Mereka seringkali diperlakukan sama dengan siswa pada umumnya, artinya pembelajaran atau pelayanan pendidikan yang diberikan sama persis dengan siswa lainnya yang tidak mengalami kesulitan belajar. Selain itu guru masih kurang

pemahamannya tentang pelayanan yang seharusnya di berikan kepada siswa berkesulitan belajar ini. Akibatnya prestasi yang ditunjukkan oleh siswa berkesulitan belajar tersebut menunjukkan ketidaksesuain dengan potensi yang dimilikinya.

Apabila guru memiliki siswa yang mengalami kesulitan belajar matematika, maka guru harus menangani dan memberikan pelayanan yang tepat, disinilah ketujuh layanan bimbingan konseling tersebut digunakan. (Fitiria:2017)

Berdasarkan penjelasan diatas, koordinasi bimbingan konseling dengan guru bidang studi menghadapi siswa berkesulitan belajar matematika bertujuan untuk mengetahui karakteristik siswa yang mengalami kesulitan belajar matematika, mendalami implementasi layanan bimbingan konseling dalam pembelajaran matematika, mengetahui kekeliruan umum yang dilakukan oleh siswa berkesulitan belajar, mengetahui penyebab dan bagaimana cara menanggulanginya. 


\section{HASIL PENELITIAN DAN PEMBAHASAN}

Koordinasi mempunyai tujuan untuk mengarahkan pelaksanaan suatu kegiatan agar dapat berjalan terarah, terpadu, dan sertasi walaupun didalamnya terdapat berbagai individu yang berlainan tugas atau fungsinya agar bisa mencapai tujuan bersama. Koordinasi bimbingan konseling dengan guru bidang studi sangat dibutuh kan dalam penanggulangan siswa berkesulitan belajar, khususnya lagi disini siswa yang berkesulitan belajar matematika. Siswa yang berkesulitan belajar matematika sangat membutuhkan perhatian khusus karena jika dibiarkan menyebabkan siswa berkesulitan dalam pemecahan masalah dikehidupannya sehari-hari. Siswa seperti ini biasanya butuh figur yang mengayominya untuk agar tidak bertindak seolah tidak peduli dengan keterbatasannya. Guru bidang studi matematika disini yang memiliki peranan untuk menumbuhkan ketertarikan siswa terhadap matematika dan menkoordinir situasinya agar siswa bisa mudah memahami materi yang disampaikan oleh guru tersebut. (Zamratul:2018)

Dalam suatu kelas tidak semua siswa bisa mengikuti pembelajaran yang diberikan oleh gurunya dengan baik. Ada siswa yang mengalami kesulitan belajar, apalagi yang kita bahas disini mengenai bidang studi matematika, yang mana bidang studi ini adalah yang dianggap paling sulit bagi siswa, dimana matematika ini bukan sekedar hanya menggunakan intelektualitas dalam berhitung tetapi juga dalam bernalar, berfikir, dan segala jenis skill yang biasa digunakan dalam penyelesaian masalah dalam kehidupan seharihari. Walaupun disini dikatakan baisa digunakan dalam kehidupan sehari-hari tetapi tidak semua siswa yang mempunyai skill ini, oleh sebab itu diperlukan dukungan dari sekitarnya, termasuk yang paling penting ialah guru bidang studi matematika itu sendiri. (Nainul:2016)

Berkesulitan belajar matematika itu sendiri biasa disebut dengan diskalkulia (dyscalculis). Istilah ini memiliki konotasi medis, yang berpersepsi bahwa adanya keterkaitan dengan gangguan syaraf pusat. Berkesulitan belajar matematika yang berat menurut Kirk disebut akalkulia (acalculia).
Menurut Lerner, ada beberapa karakteristik atau ciri-ciri anak berkesulitan belajar matematika, yaitu (1) adanya gangguan dalam hubungan keruangan, (2) abnnormalitas persepsi visual, (3) asosiasi visual-motor, (4) perseverasi, (5) kesulitan mengenal dan memahami simbol, (6) gangguan penghayatan tubuh, (7) kesulitan dalam bahasa dan membaca, dan (8) Performance IQ jauh lebih rendah dari pada skor Verbal IQ. (Yudha:2018)

\section{a.Gangguan Hubungan Keruangan}

Konsep hubungan keruangan seperti atasbawah, puncak-dasar, jauh-dekat, tinggi-rendah, depan-belakang, dan awal-akhir pada umumnya sudah dipahami oleh siswa saat mereka masuk SD. Siswa mendapatkan pemahaman tentang banyak konsep hubungan keruangan itu pada saat mereka berkomunikasi dengan lingkungan sosial mereka atau melalui games yang biasa dilakukan guna menstimulasi perkembangannya.

Namun, siswa berkesulitan belajar sering mengalami kesulitan dalam berkomunikasi dan lingkungannya juga sering tidak mensupport terbentuknya suatu kondisi yang kondusif demi terjalinnya komunikasi antarmereka. Adanya situasi intrinsik yang diduga karena adanya disfungsi otak dan situasi ekstrinsik berupa lingkungan sosial yang tidak menunjang terselenggaranya komunikasi dapat menjadi penyebab siswa mengalami gangguan dalam mendapatkan pemahaman tentang konsepkonsep hubungan keruangan. Gangguan ini bisa menjadi penyebab siswa terganggu pemahamannya tentang sistem bilangan secara keseluruhan. Siswa bisa jadi tidak bisa merasakan jarak antara angka-angka pada garis bilangan, dan lebih parahnya siswa juga tidak mengetahui bahwa angka 5 lebih dekat ke 6 dari pada ke 10. (Ronny:2018)

\section{b. Abnormalitas Persepsi Visual}

Siswa berkesulitan belajar matematika sering mengalami kesulitan untuk melihat berbagai objek dalam hubungan dengan kelompok atau set. Kesulitan seperti itu merupakan salah satu gejala adanya abnormalitas persepsi visual. Kemampuan melihat berbagai objek dalam kelompok merupakan hal yang 
dasar yang sangat penting yang memungkinkan siswa dapat secara cepat mengidentifikasikan jumlah objek dalam suatu kelompok. (Indina:2015)

Siswa yang menngidap abnormalitas persepsi visual ini juga sering tidak mampu membedakan bentuk-bentuk geometri. Kesulitan ini juga menjadi penyebab siswa kesulitan dalam belajar matematika terutama dalam memperlajari dan memahami berbagai simbol.

\section{c. Asosiasi Visual-Motor}

Siswa berkesulitan belajar matematika sering tidak dapat menghitung benda-benda secara berurutan sambil menyebutkan bilang "satu, dua, tiga, empat, lima". Siswa mungkin baru memegang benda yang ketiga tetapi telah mengucapkan "lima", atau sebaliknya. Siswa jenis ini biasanya menghafal bilangan tanpa megetahui maknanya.

\section{d.Perseverasi}

Ada siswa yang perhatiannya melekat pada satu oobjek saja dalam jangka waktu yang relatif lama. Gangguan perhatian ini lah yang biasanya disebut dengan perseverasi. Siswa ini mungkin pada awalnya bisa menyelesaikan tugas dengan baik, tetapi lama-kelamaan perhatiannya melekat pada suatu objek tertentu. Siswa yang mengidap gangguan ini biasa nya memgerjakan

soal matematika tanpa memperhatikan kaitannya.

\section{e. Kesulitan Mengenal dan Memahami Simbol}

Siswa berkesulitan belajar matematika sering mengalami kesulitan dalam mengenal dan menggunakan simbol-simbol matematika , seperti :,,$+-=,>,<$, dan lainnya. Kesulitan ini bisa disebabkan oleh adanya gangguan memori juga gangguan persepsi visual.

\section{f. Gangguan Penghayatan Tubuh}

Siswa berkesulitan belajar matematika sering memperlihatkan adanya gangguan penghayatan tubuh (body image). Siswa seperti ini merasa sulit untuk memahami hubungan bagian-bagian dari tubuhnya sendiri. Jika siswa diminta untuk menggambarkan tubuhorang misalnya, mereka tidak bisa menggambarkannya dengan lengkap atau menempatkan posisi nya dengan salah.

\section{g.Kesulitan dalam Bahasa dan Membaca}

Matematika itu sendiri pada hakikatnya adalah simbolis. Oleh sebab itu, kesulitan dalam bahasadapat berpengaruh terhadap kemampuan siswa dibidang matematika. Soal matematika berbentuk cerita menuntut kemampuan membaca untuk memecahkannya. Karenanya, siswa yang mengalami gangguan ini akan kesulitan menjawab soal matematika berbentuk cerita.

\section{h.Nilai PIQ Jauh Lebih Rendah daripada Nilai VIQ}

Hasil tes intelegensi dengan menggunakan WISC (Wechsler Intelligence Scale for Children) menunjukkan bahwa siswa berkesulitan belajar matematika memiliki nilai PIQ lebih rendah daripada VIQ. Tes intelegensiini memiliki dua subtes, yaitu : tes verbal dan tes kinerja (performance). Subtes verbal yang dilakukan

berupa informasi, persamaan, aritmatika, perbendaharaan kata, dan pemahaman. Sedangkan subtes kinerja diantaranya adalah melengkapi gambar, menyusun gambar, menysun balok, menyusuk objek, dan coding.

Guru bidang studi dalam menangani siswa yang berkesulitan belajar matematika, perlu menyadari peranannya terhadap bimbingan konseling dan media atau layanan-layanan yang diperlukan dalam pembelajaran matematika di kelas.(Dwi Tegar:2018)

Guru bidang studi biasanya memiliki peranan terhadap bimbingan dan konseling, yaitu :

\section{a.Guru sebagai Informatory}

Guru bidang studi matematika dalam kinerjanya dapar berperan sebagai informator, peranan ini mempunyai kaitan dengan tugasnya membantu guru bimbingan konseling dalam mensosialisasikan layanan bimbingan konseling kepada siswa pada umumnya. 


\section{b.Guru sebagai Fasilitator}

Guru berperan sebagai fasilisator terutama ketika dilangsungkan layanan bimbingan konseling dalam pembelajaran matmatika dikelas. Disini guru dituntut memahami tentang keterampilan belajar yang perlu dikuasai siswa dalam pembelajaran matematika.

\section{c. Guru sebagai Kolaboratan}

Sesama tenaga pendidik di sekolah, guru bisa berperan sebagai kolaboratan, misalnya dalam penyelenggaraan berbagai jenis layanan orientasi informasi.

Koordinasi bimbingan konseling dengan guru bidang studi sangat di perlukan untuk membantu siswa dalam mengatasi kesulitan dalam pembelajaran matematika. Guru bidang studi

matematika disini dirasa perlu untuk mengimplementasikan layanan bimbingan konseling dalam pembelajarannya. (Firda:2019)

Layanan bimbingan konseling seharusnya memang diterapkan oleh semua guru bidang studi tidak hanya guru bidang studi matematika saja. Tetapi dalam kenyataannya di sekolah, banyak guru yang tidak menerapkan bahkan tidak paham pentingnya layanan bimbingan konseling ini, bisa jadi ini adalah akibat dari banyaknya tugas guru yang tidak hanya bertugas mengajarkan siswa dikelas, guru bidang studi sekarang dituntutut untuk mengerjakan tugas administrasi sekolah, dan singkatnya waktu pengajaran yang membuat guru bidang studi merasa tidak sempat jika harus mengimplementasikan layanan bimbingan konseling dalam kelas.

Layanan bimbingan konseling yang dimaksudkan dan implementasinya dalam pembelajaran matematika, diantaranya :

\section{Layanan Orientasi}

Layanan orientasi merupakan suatu layanan terhadap siswa disekolah yang berelasi dengan tatapan kedepan dan tentang sesuatu yang baru.

Layanan orientasi ini biasanya diberikan saat siswa menginjakkan kaki ke sekolah barunya, pihak sekolah memberikan perkenalan tentang sekolah tersebut kepada siswa baru. Itu juga dilakukan oleh guru bidang studi memberikan perkenalan dan menjelaskan mekanisme pembelajaran dengannya sebelum masuk pada materi pembelajaran.

\section{Layanan Informasi}

Layanan informasi merupakan bentuk usahausaha membekali siswa dengan pengetahuan dan paham tentang lingkungan hidupnya dan tentang proses perkembangan anak muda.

Pada layanan ini guru bidang studi matematika memberikan pengetahuannya, dan berusa agar siswa yang ada dikelas memahami apa yang berusaha ia sampaikan dan bisa mengikuti pembelajaran matematika dengan baik.

\section{Layanan Penempatan dan Penyaluran}

Layanan penempatan dan penyaluran ini diupayakan untuk membantu individu yang mengalami mismatch. Layanan ini juga berusaha memperkecil kemungkinan kondisi mismatch yang terjadi pada siswa sehingga siswa dapat mengembangkan potensinya secara optimal.

Guru bidang studi matematika melakukan layanan ini untuk mengklasifikasikan siswa menurut tingkatannya dalam pembelajaran matematika, misal : siswa yang berkesulitan belajar matematika diberikan tempat duduk pada barisan depan agar lebih bisa memahami apa yang dijelaskan oleh guru bidang studi matematika, sedangkan siswa yang mempunyai kelebihan dalam belajar matematika bisa disalurkan sebagai kontestan dalam olimpiade atau kejuaraan matematika lainnya.

\section{Layanan Penguasaan Konten}

Layanan penguasaan konten adalah bantuan yang diberikan kepada siswa untuk menguasai kemampuan atau kompetensi tertentu.

Guru bidang studi matematika memberikan bantuan dan pengjaran agar siswa bisa menguasai matematika, dengan penguasaan konten yang berupa pembelajaran matematika ini diharapkan siswa bisa memenuhi kebutuhannya terhadap matematika untuk menyelesaikan masalah dalam kehidupannya. 


\section{Layanan Konseling Perseorangan}

Layanan ini merupakan bantuan konseling yang dilakukan oleh guru terhadap siswanya untuk mengatasi masalah pribadi siswa tersebut.

Disini guru bidang studi matematika mengatasi kesulitan belajar matematika setelah memberikan pencerahan kepada siswa tersebut untuk mengetahui masalah nya dalam mempelajari matematika dan bisa menyelesaikan masalah tersebut sendirian.

\section{Layanan Bimbingan Kelompok}

Layanan ini maksudnya pemberian bantuan dalam kegiatan kelompok kepada siswa. Bila dikaitkan dengan guru bidang studi matematika, guru bisa memberikan bimbingan belajar bagi siswa yang berkesulitan belajar matematika untuk membantu siswa berkesulitan belajar matematika memahami persoalan matematika.

\section{Layanan Konseling Kelompok}

Konseling kelompok merupakan layanan dalam bimbingan konseling yang dilaksanakan dalam konsep kelompok untuk membantu konseli mengentaskan permasalahannya (Amalia, 2019).Layanan ini memungkin kan siswa dengan dibimbing oleh guru memecahkan masalahnya bersama-sama dengan anggota kelompok lainnya. Dalam layanan konseling kelompok, dinamika kelompok harus dapat dikembangkan dengan baik, hingga mendukung tercapainya tujuan layanan secara efektif.

\section{Layanan Konsultasi}

Layanan konsultasi yang dimaksudkan disini adalah layanan konseling yang dilaksanakan guru terhadap siswa yang memungkinkannya memperoleh wawasan, pemahaman dan cara-cara yang perlu dilaksanakannya dalam menangani kondisi atau permasalahan pihak ketiga.

\section{SIMPULAN}

Matematika menjadi bidang studi paling sulit bagi siswa, dalam pembelajaran matematika guru bidang studi dituntut mampu membawa siswa yang tidak berkesulitan belajar matematika dan siswa yang berkesulitan belajar matematika untuk bisa memahami materi yang disampaikannya.
Peranan guru bidang studi sangat penting disini dalam penanganan siswa berkesulitan belajar matematika, karena dinilai yang paling strategis kedudukannya dengan siswa. Pengimplementasian layanan bimbingan konseling dalam pembelajaran matematika dianggap bisa mengatasi siswa berkesulitan belajar matematika. Layanan tersebut diantaranya : layanan orientasi, layanan informasi, layanan penempatan dan penyaluran, layanan penguasaan konten, layanan konseling perorangan, layanan bimbingan kelompok, layanan konseling kelompok dan layanan konsultasi.

\section{DAFTAR PUSTAKA}

Adriani, Melisa. 2013. Kerjasama Guru Bimbingan dan Konseling dengan Guru Mata Pelajaran dalam Mengembangkan Cara Belajar Siswa. Jurnal Ilmiah Konseling. Vol. 2, No. 1.

Aini, Zamratul. 2018. Kontribusi Penguatan Guru Mata Pelajaran dan Kepercayaan Diri Siswa Terhadap Keaktifan Siswa dalam Belajar. Jurnal Kajian Konseling dan Pendidikan. Vol. 1, No. 1.

Amalia, Rizki. 2019. Intervensi Konselor Sekolah untuk Meningkatkan Self Esteem bagi Anak Keluarga Broken Home. Jurnal Pendidikan Tambusai. Vol 1, No.2.

Falah, Nailul. 2016. Peningkatan Layanan Bimbingan dan Konseling Melalui Pelatihan Pembuatan Media Bimbingan pada Konselor Sekolah di MAN Lab. UIN Yogyakarta. Jurnal Hisbah. Vol. 13, No. 1.

Fitriani, Yudha. 2018. Kolaborasi Guru Bimbingan Konseling Wali Kelas dalam Mengatasi Kesulitan Belajar Siswa Kelas VII di MTs

Negeri Babadan Baru. Jurnal

Transformatif. Vol. 2, No. 2.

Gunawan, Ronny. 2018. Peranan Tata Kelola Layanan Bimbingan dan Konseling Bagi Siswa di Sekolah. Jurnal Selaras Kajian Bimbingan dan Konseling Serta Psikologi Pendidikan. Vol. 1, No. 1.

Halawati, Firda. 2019. Pengaruh Model Pembelajaran Matematika Realistik Berbasis Media Terhadap Kesulitan Belajar 
Siswa. Jurnal Edukasi Matematika dan Sains. Vol. 6, No. 1.

Hasanah, Noor. 2016. Upaya Guru dalam Mengatasi Siswa Berkesulitan Belajar Matematika di Kelas IV SDIT Ukhuwah Banjarmasin. Jurnal PTK dan Pendidikan. Vol. 2, No. 2.

Kasih, Fitiria. 2017. Model Pengembangan Layanan Bimbingan dan Konseling dalam Membentuk Tingkah Laku Remaja bagi Orang Tua Tipe Permisif. Jurnal Counseling Care. Vol. 1, No. 2.

Maulana, Riki. 2016. Pengembangan Model Bimbingan Kelompok Berbasis Islami untuk Meningkatkan Kecerdasan Sosial Siswa SMK. Jurnal Psikologi Pendidikan dan Konseling. Vol. 2, No. 1.

Mulyono, Abdurrahman. 2015. Pendidikan Bagi Anak Berkesulitan Belajar. Jakarta: PT. Rineka Cipta.

Nisa, Afiatin. 2018. Analisis Kenakalan Siswa dan Implikasinya Terhadap Layanan Bimbingan Konseling. Jurnal Bimbingan Konseling. Vol. 4, No. 2.

Rosdianah, Kartinah, dan Muhtarom. 2019. Analisis Faktor Penyebab Kesulitan Belajar Matematika pada Materi Garis dan Sudut Kelas VII Sekolah Menengah Pertama. Jurnal Matematika dan Pendidikan Matematika. Vol. 1, No. 5.

Rozak, Abdul. 2018. Analisis Pelaksanaan Bimbingan Belajar dalam Mengatasi Kesulitan Belajar Siswa. Journal of Education and Instruction. Vol. 1, No. 1.

Simanjuntak, Hinsa. 2017. Peranan Bimbingan dan Konseling pada Siswa dalam Mengatasi Kesulitan Belajar oleh Siswa Kelas XII SMA Negeri 1 Parbuluan. Jurnal Penelitian, Pemikiran, dan Pengabdian. Vol. 5, No. 2.

Tarjiah, Indina. 2015. Pengembangan Model Pembelajaran Matematika Bagi Siswa Berkesulitan Belajar di Sekolah Dasar Inklusi. Jurnal Ilmiah VISI PPTK PAUDNI. Vol. 10, No. 2.

Yaniswantoro, Dwi Tegar. Tanpa Tahun. Peran Konselor Untuk Membantu Siswa yang Mengalami Kesulitan Belajar Bahasa Inggris di SMPN 2 Wlingi Kabupaten Blitar. Jurnal Penelitian Bimbingan Konseling. Vol. 1, No. 9. 